Article

\title{
The Ability of a Nanofiltration Membrane to Remove Hardness and Ions from Diluted Seawater
}

\author{
Amir Abbas Izadpanah ${ }^{1, *}$ and Asghar Javidnia ${ }^{2}$
}

1 Department of Chemical Engineering, Engineering Faculty, Persian Gulf University, Bushehr 7516913798, Iran

2 ParsianFarAb Co., Motahheri Building, P.O. Box 7514944968, Bushehr 7514944968, Iran;

E-Mail: javidnia@parsian-farab.com

* Author to whom correspondence should be addressed; E-Mail: izadpanah@pgu.ac.ir;

Tel.: +98-771-422-2169; Fax: +98-771-454-0376.

Received: 19 January 2012; in revised form: 1 March 2012 / Accepted: 1 March 2012 /

Published: 23 March 2012

\begin{abstract}
In this work, the ability of a commercial spiral-wound nanofiltration membrane to remove hardness and ions from diluted seawater was studied. Experiments were carried out in the pressure range of 4-10 bar. Analyses of the samples, and permeates at different pressures, were performed and the effects of the trans-membrane pressure on the permeate flux were investigated. The results show that this nanofiltration membrane is capable of retaining $96-98 \%$ of the total hardness, $79-89 \%$ of the electrical conductivity and $79-89 \%$ of the total dissolved solid (TDS). Our results are in good agreement with those reported by the manufacturing company.
\end{abstract}

Keywords: nanofiltration; hardness; potable water; membrane; seawater

\section{Introduction}

In Iran, surface water is frequently used to produce potable water. However, due to droughts, the use of groundwater for the production of potable water is currently increasing. Over the past decades, seawater has become an important source of fresh water [1] due to changing weather patterns, increased industrialization and recent population increases in areas where local supplies of high-quality fresh water are less than adequate. 
A nanofiltration membrane is a type of pressure-driven membrane that has properties in between those of ultrafiltration and reverse osmosis membranes. Nanofiltration membranes have the advantages of providing a high water flux at low operating pressure and maintaining a high salt and organic matter rejection rate [2]. The nanofiltration process has the benefits of ease of operation, reliability and comparatively low energy consumption [3] as well as highly efficient pollutant removal. This helps to minimize scale formation on the equipment involved in both reverse osmosis and thermal desalination processes. Therefore, nanofiltration membranes have received interest worldwide.

Recently, nanofiltration membranes have been employed in pre-treatment unit operations in both thermal and membrane seawater desalination processes. This has resulted in a reduction in chemicals used in pre-treatment processes as well as a decrease in the energy consumption and water production costs and, therefore, has led to more environmentally friendly processes. To predict nanofiltration membrane performance, a systematic study on the filtration performance of selected commercial nanofiltration membranes against brackish water and seawater is required.

Schaep et al. [4] studied the reduction in hardness in groundwater achieved by nanofiltration membranes. In their experiments, a cross-flow filtration cell containing flat sheet membranes was used. They studied three commercial nanofiltration membranes and concluded that the performance of the UTC20 nanofiltration membrane for reducing hardness was better than that of the NF70 and UTC60 nanofiltration membranes. At 10 bar transmembrane pressure the calcium retention for UTC20 nanofiltration was $96 \%$.

Gorenflo et al. [5] examined the nanofiltration of German groundwater with high hardness and natural organic matter (NOM) content. They used NF200B nanofiltration with 5.5 bar transmembrane pressure and a water recovery rate between $60 \%$ and $85 \%$. Their results showed almost complete rejection (>95\%) of NOM. Due to the high concentration of $\mathrm{SO}_{4}{ }^{2-}$ present and presumably due to the complexation of $\mathrm{Ca}^{2+}$ with humic substances, the rejection of $\mathrm{Ca}^{2+}$ and $\mathrm{Mg}^{2+}$ was unexpectedly high ( $\sim 74 \%$ and $>86 \%$, respectively) compared to a pure $\mathrm{CaCl}_{2}$ solution $(\mathrm{R}(\mathrm{CaC} 1) \sim 45 \%)$.

Orecki et al. [6] studied surface water treatment by nanofiltration. They used a composite membrane, AFC30, with cross-flow and transmembrane pressure between 10-25 bar in their experiments. They concluded that the use of nanofiltration for treating surface water can remove completely total organic carbon (TOC) and reduce the sulfate content by approximately $90-99 \%$, the carbonate content by $82 \%$ and the monovalent salt content by approximately $40-55 \%$. Furthermore, their study demonstrated a significant reduction in inorganic carbon $(62.8 \%)$, electrical conductivity $(68.4 \%)$ and total hardness $(85.2 \%)$.

Ghizellaoui et al. [7] studied the softening of drinking water of Constantine (Algeria), city supplied by underground and surface water using NanoMax-50 nanofiltration membranes. They studied the effects of pressure, flow rate and temperature on the nanofiltration performance. The maximum transmembrane pressure was 2 bar. The results indicated that the retention of both cations and anions increased with the applied pressure. The retention of divalent cations $\left(\mathrm{Ca}^{2+}\right.$ and $\left.\mathrm{Mg}^{2+}\right)$ was higher than that of monovalent cations $\left(\mathrm{Na}^{+}\right.$and $\left.\mathrm{K}^{+}\right)$.

Ghizellaoui et al. [8] studied the use of nanofiltration for partial softening of very hard water. Their study was based on the elimination of one aspect of the temporary hardness of Hamma underground water, which provides drinking water for Constantine City. Two techniques were used to obtain a partial softening based on applying weak pressure $(0.5,1,2$ bar) or relatively high pressure (4-16 bar) 
to feed water. Rates of retention reached $50 \%$ for $\mathrm{Ca}^{2+}$ and $40 \%$ for $\mathrm{HCO}_{3}{ }^{-}$at relatively high pressures and $34 \%$ for $\mathrm{Ca}^{2+}$ and $30 \%$ for $\mathrm{HCO}_{3}{ }^{-}$at low pressures.

To determine the suitability of nanofiltration as a pre-treatment unit operation in the desalination process, Hilal et al. [9] used three commercial nanofiltration membranes (NF90, NF270, N30F) to treat highly concentrated $(\mathrm{NaCl})$ salt solutions, with concentrations ranging from 5,000 to 25,000 ppm, a salinity level similar to that of sea water. The main parameters considered were the feed pressure and salt concentration. The results showed that the rejection of $\mathrm{NaCl}$ and the flux for all membranes increased linearly with the trans-membrane pressure and decreased with the salt concentration. For a salinity of 5,000 ppm and a pressure of 9 bar, the experimental results showed that NF90 could achieve a salt rejection of up to $95 \%$, whereas its rejection dropped to $41 \%$ at a salinity of $25,000 \mathrm{ppm}$ and the same pressure.

Costa and de Pinho [10] studied the performance and estimated cost of nanofiltration for surface water treatment in drinking water production. The spiral-wound Filmtec NF200B-400 membrane, with a molecular weight cutoff (MWCO) of $200 \mathrm{Da}$, was used in the nanofiltration experiments. Their nanofiltration experiments were conducted in total recirculation and concentration mode. In total recirculation mode the transmembrane pressure was 5-25 bar. Finally the 6 bar transmembrane pressure was chosen for operation of nanofiltration plant. The membrane was characterized in terms of its hydraulic permeability and solute rejection. The solutes studied were sucrose, glucose and the salts $\mathrm{NaCl}, \mathrm{CaCl}_{2}$ and $\mathrm{MgSO}_{4}$. The retention coefficients for these substances were found to be $94 \%, 97 \%$, $55 \%, 64 \%$ and $98 \%$, respectively. Furthermore, the retention coefficient of salts for Tagus River water was found to be $86 \%$, and sulfate ions and total organic carbon (TOC) were completely retained by this membrane.

Recently Galanakis et al. [11] performed nanofiltration of brackish groundwater by using a poly-piperazine membrane. They used cross flow nanofiltration module and low transmembrane pressure (6-10 bar). Their samples have hardness and salinity values up to $762 \mathrm{mg} \mathrm{CaCO}_{3}$ and $1,803 \mathrm{mg} \mathrm{NaCl} / \mathrm{L}$, respectively. Their results showed that this nanofiltration membrane could remove $70-76 \%$ of hardness and $44-66 \%$ of salinity.

Because properties of groundwater near the coast are close to diluted sea water, in this study we attempt to produce drinking water from groundwater near the coast. Therefore the ability of a commercial nanofiltration membrane manufactured by CSM Co. (S. Korea), NE4040-90, to retain hardness and ions in three samples of diluted seawater (Persian Gulf) was studied, and the effects of the trans-membrane pressure on the permeate flux and the retention coefficient of hardness and various ions were investigated.

\section{Materials and Methods}

The experimental setup included a tank, a pump for feeding the sample water, a carbon filter and a micro filter for pre-treatment of the inlet water, a high-pressure pump for producing trans-membrane pressure, a high-pressure holder for the nanofiltration membrane, two flow meters for measuring the permeate and retentate, and three pressure gauges. A schematic diagram of the experimental setup is shown in Figure 1. 
Figure 1. Schematic of the experimental setup.

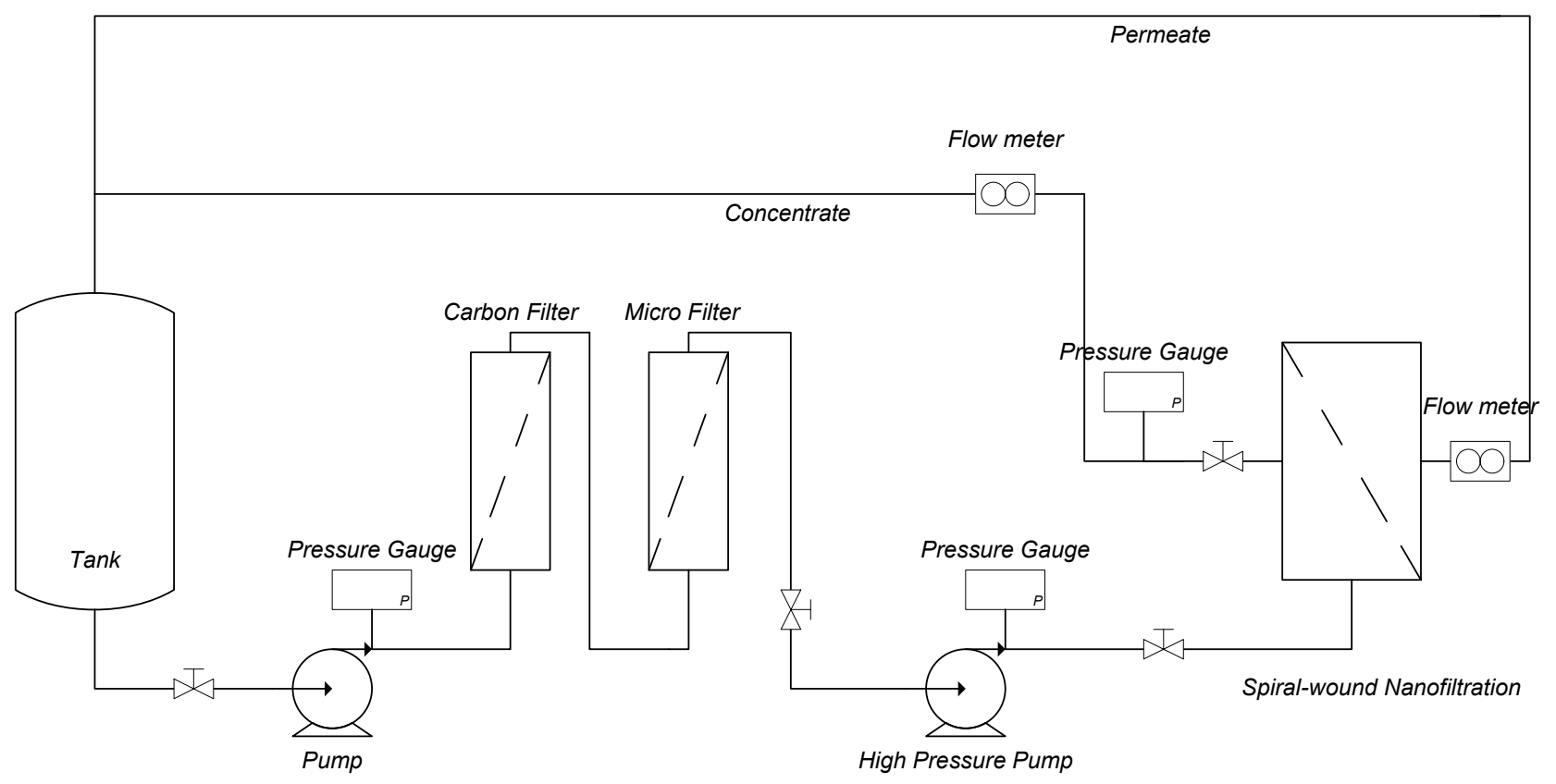

A spiral-wound nanofiltration membrane manufactured by CSM Co. (Seoul, South Korea), NE4040-90, with dimensions of $10.16 \times 101.6 \mathrm{~cm}(4 \times 40 \mathrm{in})$, an effective membrane area of $7.9 \mathrm{~m}^{2}$ $\left(85 \mathrm{ft}^{2}\right)$, a monovalent ion $(\mathrm{NaCl})$ rejection rate of $85-95 \%$ and a divalent ion $\left(\mathrm{CaCl}_{2}\right)$ rejection rate of $90-95 \%$ was used. The experiments were carried out at ambient temperature in total re-circulation mode, i.e., both the concentrate and the permeate streams were re-circulated into the feed tank. The volume of the feed tank was 500 liters. It was filled with about 400 liters of initial samples. The volume of water in the remainder of experimental setup was about 10 liters. Re-circulating the concentrate and the permeate streams into the feed tank maintained constant concentration of the feed. The trans-membrane pressure and volumetric flow rate were adjusted using the concentrate (reject) outlet valve.

The seawater was diluted with drinking water of Bushehr city. Its calcium and magnesium concentration were $254 \mathrm{mg} / \mathrm{L}$ and $34 \mathrm{mg} / \mathrm{L}$. This diluted sea water was used throughout the experiments. Before beginning experiments, an initial sample was taken from the feed tank and analyzed. During the experiments, samples were taken from the permeate stream at different pressure.

All analyses on initial samples and permeates were carried out at the Bushehr Department of Water Treatment Works and Laboratory. Electrical conductivity (EC), salinity and total dissolved solid (TDS) were measured by a JENWAY conductivity meter model $4320 . \mathrm{Ca}^{2+}$ and $\mathrm{Mg}^{2+}$ and total hardness were indicated by titration with ethylenediaminetetraacetic acid (EDTA). Turbidity and $\mathrm{pH}$ were measured by Hach turbidity meter model 2100p and EcoMet P25 pH meter, respectively [12].

\section{Results and Discussion}

Experiments were carried out with three samples of diluted seawater (Persian Gulf). If concentration of TDS, total hardness and salinity are higher than the values for sample 1, the 
transmembrane pressure must be greater than 10 bar. Because the experiments were performed at transmembrane pressures less than 10 bar, these three samples was studied.

An analysis of the initial samples and permeates at various pressures is presented in Tables 1-3.

Table 1. Analysis of the feed and permeates at various pressures (Sample 1).

\begin{tabular}{lccccc}
\hline \multicolumn{1}{c}{ Analyzed Parameter } & Initial & $\begin{array}{c}\text { Permeate } \\
\text { at } 8 \text { bar }\end{array}$ & $\begin{array}{c}\text { Permeate } \\
\text { at 9 bar }\end{array}$ & $\begin{array}{c}\text { Permeate } \\
\text { at 10 bar }\end{array}$ & $\begin{array}{c}\text { Standard value } \\
\text { for potable water }\end{array}$ \\
\hline $\mathrm{pH}$ & 8.07 & 8.21 & 8.38 & 8.41 & $6.5-9$ \\
Electrical Conductivity $(\mu \mathrm{S} / \mathrm{cm})$ & 16,260 & 3,410 & 2,910 & 2,890 & - \\
TDS $(\mathrm{mg} / \mathrm{L})$ & 9,750 & 2,050 & 1,744 & 1,732 & 1,500 \\
Turbidity $(\mathrm{NTU})$ & 0.8 & 0.3 & 0.4 & 0.5 & 5 \\
Total Hardness $\left(\mathrm{mg} / \mathrm{L} \mathrm{CaCO}_{3}\right)$ & 2,940 & 104 & 68 & 76 & 500 \\
$\mathrm{Salinity}(\mathrm{g} / \mathrm{L})^{2+}$ & 7.7 & 1.5 & 1.3 & 1.3 & 0.5 \\
$\mathrm{Ca}^{2+}(\mathrm{mg} / \mathrm{L})$ & 384 & 12.8 & 11.2 & 8.0 & 250 \\
$\mathrm{Mg}^{2+}(\mathrm{mg} / \mathrm{L})$ & 475.2 & 17.28 & 9.6 & 13.44 & 50 \\
\hline
\end{tabular}

Table 2. Analysis of the feed and permeates at various pressures (Sample 2).

\begin{tabular}{lccccc}
\hline \multicolumn{1}{c}{ Analyzed Parameter } & Initial & $\begin{array}{c}\text { Permeate } \\
\text { at 6 bar }\end{array}$ & $\begin{array}{c}\text { Permeate } \\
\text { at 8 bar }\end{array}$ & $\begin{array}{c}\text { Permeate } \\
\text { at 10 bar }\end{array}$ & $\begin{array}{c}\text { Standard value } \\
\text { for potable water }\end{array}$ \\
\hline $\mathrm{pH}$ & 8.06 & 8.3 & 8.26 & 8.19 & $6.5-9$ \\
Electrical Conductivity $(\mu \mathrm{S} / \mathrm{cm})$ & 12,080 & 2,180 & 1,520 & 1,580 & - \\
TDS $(\mathrm{mg} / \mathrm{L})$ & 7,220 & 1,311 & 912 & 948 & 1,500 \\
Turbidity $(\mathrm{NTU})$ & 0.51 & 0.45 & 0.34 & 0.27 & 5 \\
Total Hardness $(\mathrm{mg} / \mathrm{L} \mathrm{CaCO})$ & 2,180 & 56.0 & 52.0 & 48.0 & 500 \\
$\mathrm{Salinity}(\mathrm{g} / \mathrm{L})_{\mathrm{Ca}^{2+}(\mathrm{mg} / \mathrm{L})}^{5.4}$ & 1.1 & 0.8 & 0.9 & 0.5 \\
$\mathrm{Mg}^{2+}(\mathrm{mg} / \mathrm{L})$ & 296 & 8.0 & 6.4 & 6.4 & 250 \\
\hline
\end{tabular}

Table 3. Analysis of the feed and permeates at various pressures (Sample 3).

\begin{tabular}{lccccc}
\hline \multicolumn{1}{c}{ Analyzed Parameter } & Initial & $\begin{array}{c}\text { Permeate } \\
\text { at } \mathbf{4} \text { bar }\end{array}$ & $\begin{array}{c}\text { Permeate } \\
\text { at 6 bar }\end{array}$ & $\begin{array}{c}\text { Permeate } \\
\text { at 8 bar }\end{array}$ & $\begin{array}{c}\text { Standard value } \\
\text { for potable water }\end{array}$ \\
\hline $\mathrm{pH}$ & 7.69 & 7.82 & 8.01 & 8.15 & $6.5-9$ \\
Electrical Conductivity & 8,280 & 1,459 & 878 & 889 & - \\
$(\mu \mathrm{S} / \mathrm{cm})$ & & & & & \\
$\mathrm{TDS}(\mathrm{mg} / \mathrm{L})$ & 4,970 & 877 & 527 & 534 & 1,500 \\
Turbidity $(\mathrm{NTU})$ & 0.6 & 0.28 & 0.25 & 0.21 & 5 \\
Total Hardness $\left(\mathrm{mg} / \mathrm{L} \mathrm{CaCO}_{3}\right)$ & 1,880 & 64 & 32 & 40 & 500 \\
$\mathrm{Salinity}(\mathrm{g} / \mathrm{L})_{\mathrm{Ca}^{2+}(\mathrm{mg} / \mathrm{L})}$ & 3.6 & 0.8 & 0.6 & 0.6 & 0.5 \\
$\mathrm{Mg}^{2+}(\mathrm{mg} / \mathrm{L})$ & 272 & 8 & 4.8 & 6.4 & 250 \\
\hline & 288 & 10.56 & 4.8 & 5.76 & 50 \\
\hline
\end{tabular}

As shown for Sample 1, the total hardness was $2,940 \mathrm{mg} / \mathrm{L} \mathrm{CaCO}_{3}$ and the salinity was $7.7 \mathrm{~g} / \mathrm{L}$; for Sample 2, the total hardness was $2,180 \mathrm{mg} / \mathrm{L} \mathrm{CaCO}_{3}$ and the salinity was $5.4 \mathrm{~g} / \mathrm{L}$; for Sample 3, the total hardness was $1,880 \mathrm{mg} / \mathrm{L} \mathrm{CaCO}_{3}$ and the salinity was $3.6 \mathrm{~g} / \mathrm{L}$. The analysis performed on these 
samples showed that their hardness and salinity characteristics were similar to those of groundwater in the Bushehr province. As mentioned previously the sea water was diluted with drinking water, and due to high calcium level in the drinking water calcium levels in the initial samples did not drop as fast as the electrical conductivity (EC) and TDS. For Sample 1, comparison between analysis of permeate at various pressure and standard values for drinking water showed that TDS for permeate was higher than standard value. Therefore nanofiltration of Sample 1 cannot provide drinking water. For Samples 2, TDS, $\mathrm{Ca}^{2+}$ and $\mathrm{Mg}^{2+}$ level of permeate at 8 bar are less than standard values but salinity level are relatively high. For Sample 3, the results revealed that nanofiltration of this Sample can provide drinking water, although the $\mathrm{Ca}^{2+}$ concentration in the permeate was much less than standard value.

The effect of the trans-membrane pressure on the permeate flux was evaluated. The results are shown in Figure 2. As shown in this Figure, the permeate flux changed linearly with the trans-membrane pressure, as is common in these systems.

Figure 2. Permeate flux vs. pressure for the three samples.

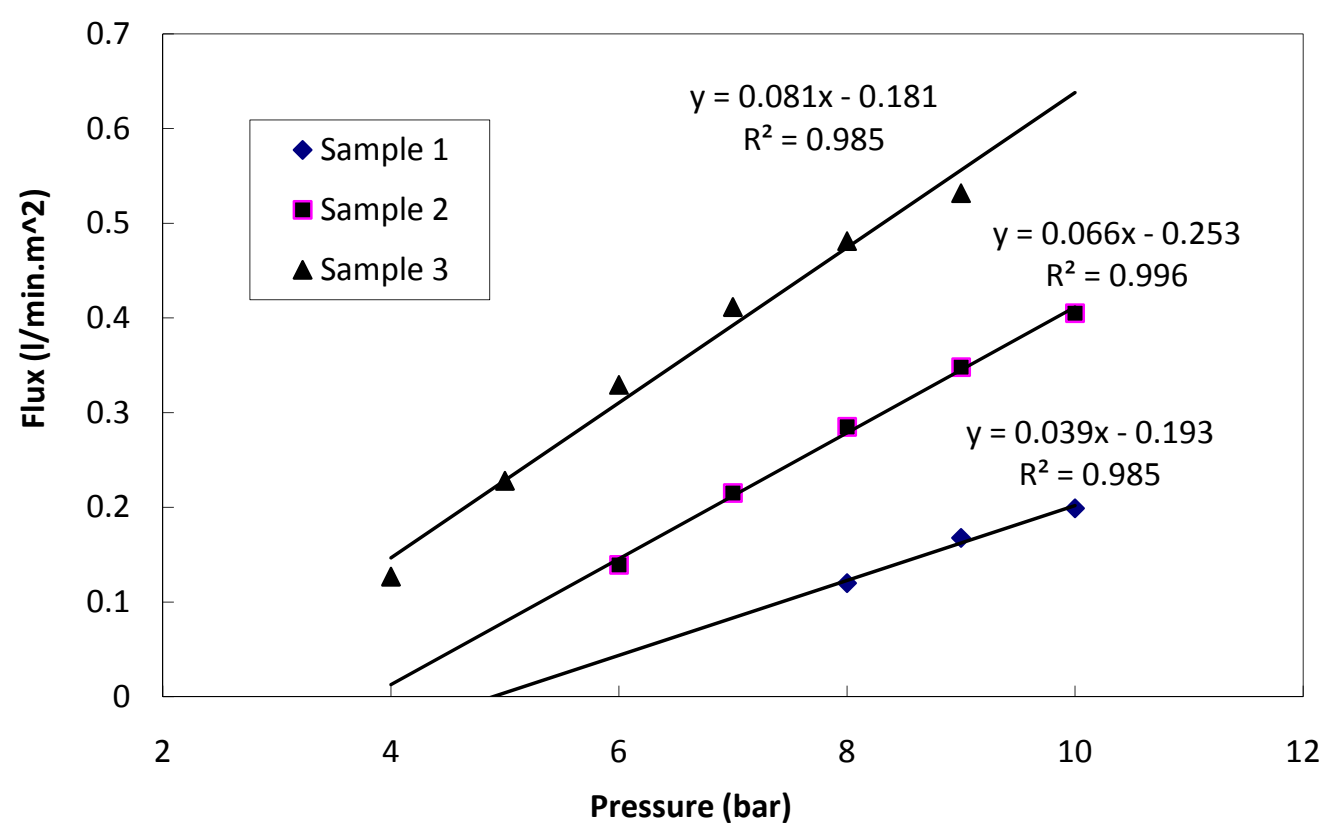

The retention percentage of various components was calculated by the following equation [13]:

$$
\% R=\frac{C_{F}-C_{P}}{C_{F}} 100
$$

where $C_{F}$ and $C_{P}$ are the concentrations in the feed and permeate, respectively. The retention percentages $(\% R)$ of $\mathrm{Ca}^{2+}, \mathrm{Mg}^{2+}$, total hardness and TDS at various pressures for three samples are presented in Tables 4-6 and depicted in Figures 3-5. 
Table 4. Retention percentage $(\% R)$ of TDS, total hardness, $\mathrm{Ca}^{2+}$ and $\mathrm{Mg}^{2+}$ at various pressures for Sample 1.

\begin{tabular}{lccc}
\hline Parameter & $\begin{array}{c}\text { Percent retention } \\
\text { at } 8 \text { bar }\end{array}$ & $\begin{array}{c}\text { Percent retention } \\
\text { at 9 bar }\end{array}$ & $\begin{array}{c}\text { Percent retention } \\
\text { at 10 bar }\end{array}$ \\
\hline TDS & 78.97 & 82.11 & 82.24 \\
Total Hardness & 96.46 & 97.69 & 97.41 \\
$\mathrm{Ca}^{2+}$ & 96.67 & 97.08 & 97.92 \\
$\mathrm{Mg}^{2+}$ & 96.36 & 97.98 & 97.17 \\
\hline
\end{tabular}

Table 5. Retention percentage $(\% R)$ of TDS, total hardness, $\mathrm{Ca}^{2+}$ and $\mathrm{Mg}^{2+}$ at various pressures for Sample 2.

\begin{tabular}{lccc}
\hline \multicolumn{1}{c}{ Parameter } & $\begin{array}{c}\text { Percent retention } \\
\text { at } \mathbf{6} \text { bar }\end{array}$ & $\begin{array}{c}\text { Percent retention } \\
\text { at } 8 \text { bar }\end{array}$ & $\begin{array}{c}\text { Percent retention } \\
\text { at 10 bar }\end{array}$ \\
\hline TDS & 81.84 & 87.37 & 86.87 \\
Total Hardness & 97.43 & 97.61 & 97.80 \\
$\mathrm{Ca}^{2+}$ & 97.30 & 97.84 & 97.84 \\
$\mathrm{Mg}^{2+}$ & 97.50 & 97.50 & 97.78 \\
\hline
\end{tabular}

Table 6. Retention percentage $(\% R)$ of TDS, total hardness, $\mathrm{Ca}^{2+}$ and $\mathrm{Mg}^{2+}$ at various pressures for Sample 3.

\begin{tabular}{lccc}
\hline Parameter & $\begin{array}{c}\text { Percent retention } \\
\text { at } \mathbf{4} \text { bar }\end{array}$ & $\begin{array}{c}\text { Percent retention } \\
\text { at 6 bar }\end{array}$ & $\begin{array}{c}\text { Percent retention } \\
\text { at 8 bar }\end{array}$ \\
\hline TDS & 82.35 & 89.4 & 89.26 \\
Total Hardness & 96.6 & 98.3 & 97.87 \\
$\mathrm{Ca}^{2+}$ & 97.06 & 98.24 & 97.65 \\
$\mathrm{Mg}^{2+}$ & 96.33 & 98.33 & 98.00 \\
\hline
\end{tabular}

Figure 3. Retention of $\mathrm{Ca}^{2+}, \mathrm{Mg}^{2+}$, total hardness and TDS vs. pressure for Sample 1.

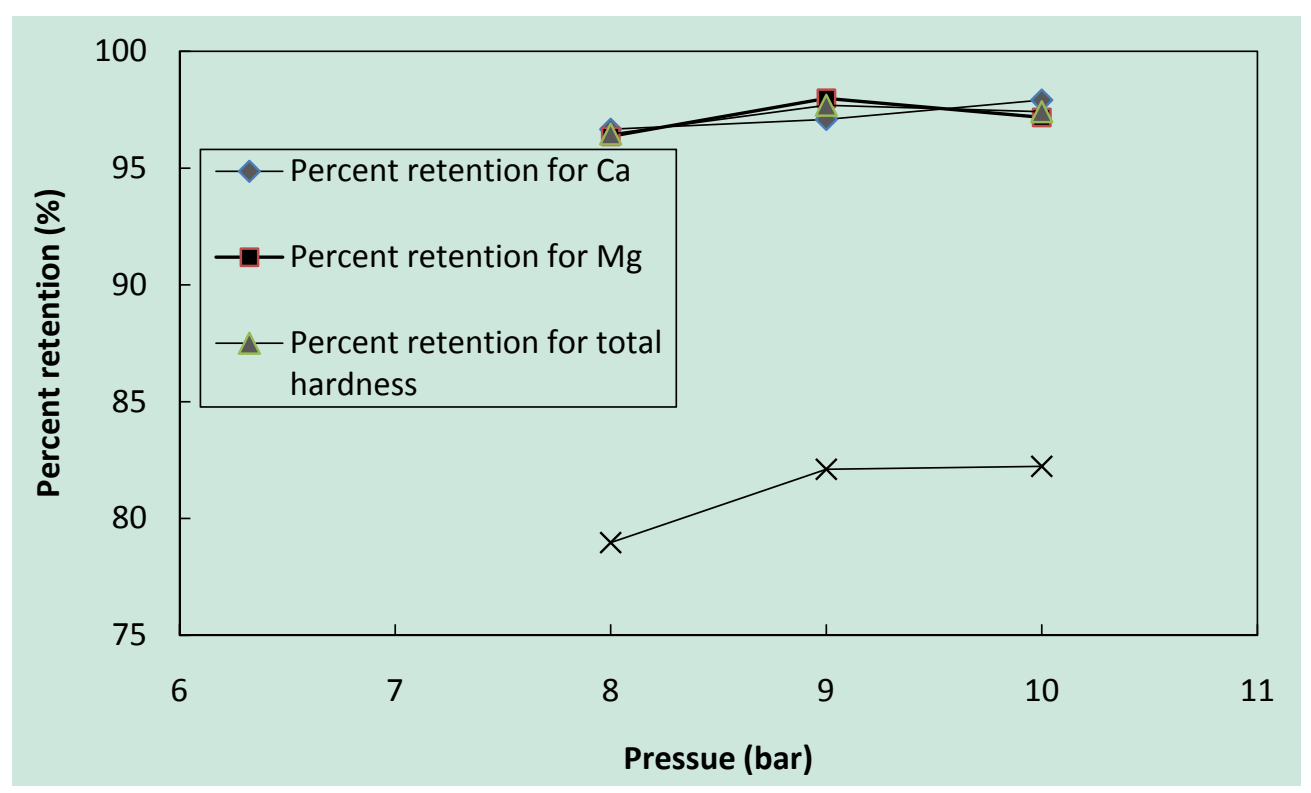


Figure 4. Retention of $\mathrm{Ca}^{2+}, \mathrm{Mg}^{2+}$, total hardness and TDS vs. pressure for Sample 2.

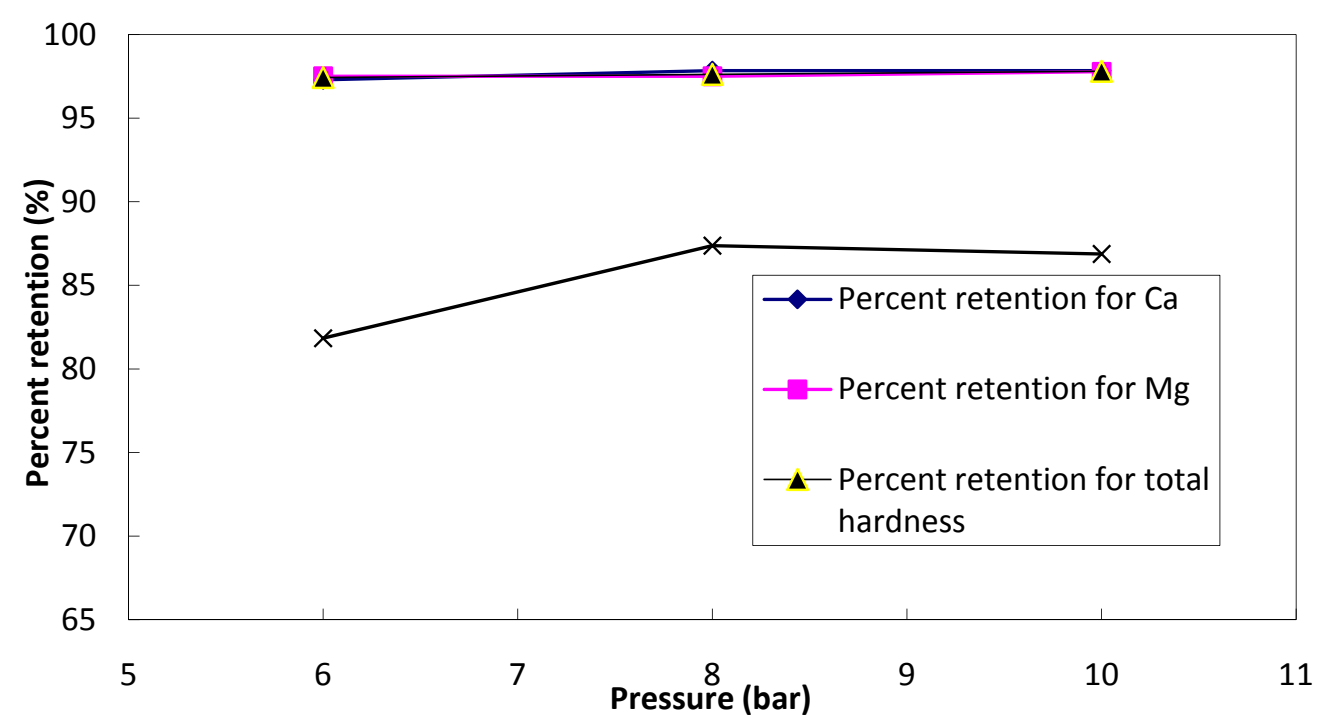

Figure 5. Retention of $\mathrm{Ca}^{2+}, \mathrm{Mg}^{2+}$, total hardness and TDS vs. pressure for Sample 3.

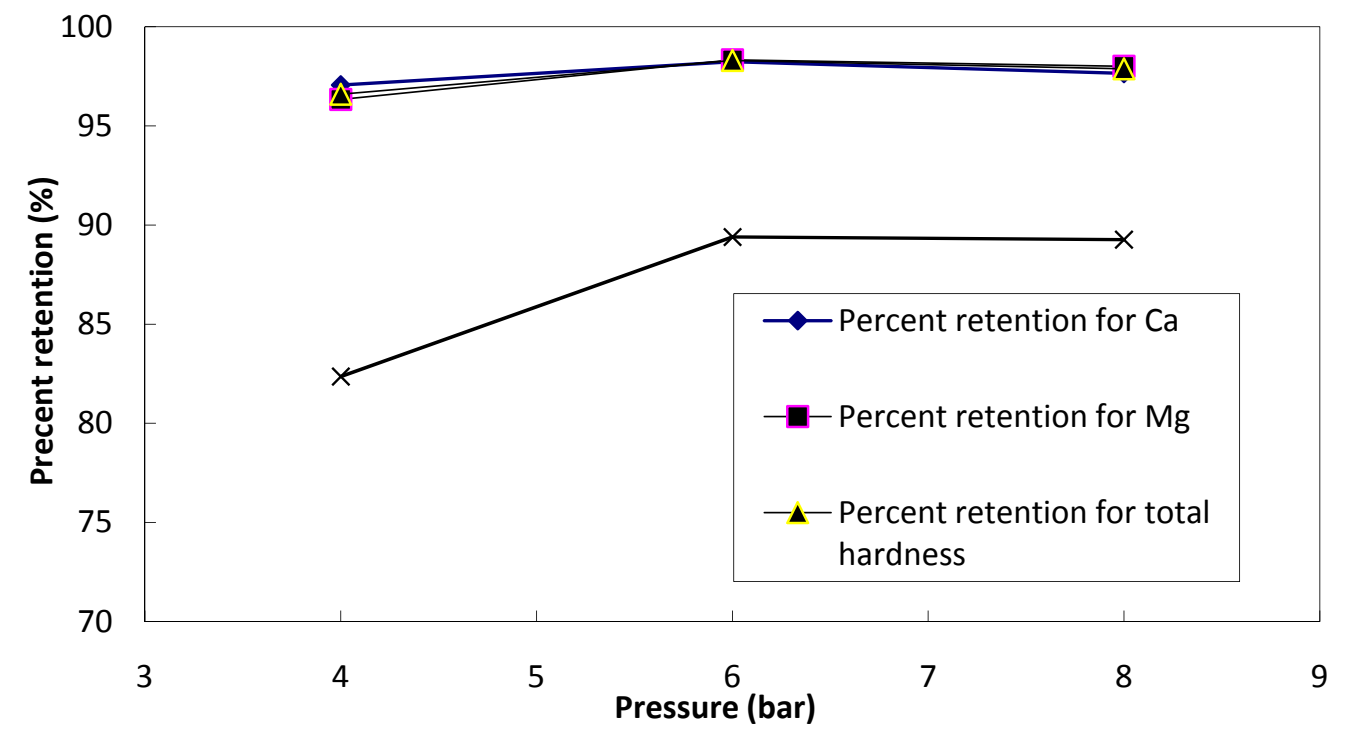

According to Table 4, for Sample 1, the retention percentages of $\mathrm{Ca}^{2+}, \mathrm{Mg}^{2+}$ and total hardness at all pressures are higher than $96 \%$, and the retention of TDS at pressures of 9 and 10 bar is higher than $82 \%$. As shown in Table 5, for Sample 2, the retention percentages of $\mathrm{Ca}^{2+}, \mathrm{Mg}^{2+}$ and total hardness at all pressures are higher than $97 \%$, and the retention of TDS at pressures of 8 and $10 \mathrm{bar}$ is $87 \%$ and $86 \%$, respectively. As can be seen, with increasing pressure, the retention percentage of TDS decreases slightly. Additionally, as presented in Table 6 for Sample 3, the retention percentages of $\mathrm{Ca}^{2+}, \mathrm{Mg}^{2+}$ and total hardness at all pressures are higher than 95\%, and the retention of TDS at pressures of 6 and 8 bar is approximately $89 \%$. Again, one can see that the retention percentage at 8 bar is slightly lower than that at 6 bar.

Comparison between $\% R$ of $\mathrm{Ca}^{2+}$ evaluated in this work and those obtained in the literature show that the performance of NE4040-90 nanofiltration to retentive $\mathrm{Ca}^{2+}$ is similar to UTC20 [4] (96\% \% $R$ 
of $\mathrm{Ca}^{2+}$ ) and better than NF200B [5] (74\%), NanoMax50 [8] (50\%) and NF200B-400 [10] (64\%). The ability of this nanofiltration to retentive $\mathrm{Mg}^{2+}(\% R$ is $95 \%)$ is better than NF200B [5] (greater than $86 \%$ ). The results show this nanofiltration can retain $95 \%$ of total hardness compared to those reported by Orecki et al. [6] 85.2\% and Galanakis et al. [11] 70-76\%.

Tables 7-9 and Figures 6-8 show the retention percentage of salinity and electrical conductivity for these samples. As presented in Table 7, for Sample 1, the retention values of salinity and electrical conductivity at pressures of 9 and 10 bar are $83 \%$ and $82 \%$, respectively. Table 8 shows that, for Sample 2, the retention values of salinity and electrical conductivity first increase with increasing pressure and then decrease. The maximum retention values of salinity and electrical conductivity for this sample are $85 \%$ and $87 \%$, respectively, and occur at a pressure of 8 bar. Furthermore, Table 9 shows a similar trend for Sample 3. The maximum retention occurs at a pressure of 6 bar, and the corresponding values for salinity and electrical conductivity are $83.33 \%$ and $89.4 \%$, respectively. The data reported in the literature show $\% R$ for $\mathrm{EC}$ is $68.4 \%$ [6] (AFC30 nanoflitration) and $\% R$ for salinity is between $44-66 \%$ [11] (poly piperazine nanofiltration).

Table 7. Retention percentage $(\% R)$ of salinity and electrical conductivity at various pressures for Sample 1.

\begin{tabular}{lccc}
\hline \multicolumn{1}{c}{ Parameter } & $\begin{array}{c}\text { Percent retention } \\
\text { at } 8 \text { bar }\end{array}$ & $\begin{array}{c}\text { Percent retention } \\
\text { at } 9 \text { bar }\end{array}$ & $\begin{array}{c}\text { Percent retention } \\
\text { at 10 bar }\end{array}$ \\
\hline Salinity & 80.52 & 83.12 & 83.12 \\
Electrical Conductivity & 79.03 & 82.10 & 82.23 \\
\hline
\end{tabular}

Table 8. Retention percentage $(\% R)$ of salinity and electrical conductivity at various pressures for Sample 2 .

\begin{tabular}{lccc}
\hline \multicolumn{1}{c}{ Parameter } & $\begin{array}{c}\text { Percent retention } \\
\text { at } \mathbf{6} \text { bar }\end{array}$ & $\begin{array}{c}\text { Percent retention } \\
\text { at } \mathbf{8} \text { bar }\end{array}$ & $\begin{array}{c}\text { Percent retention } \\
\text { at 10 bar }\end{array}$ \\
\hline Salinity & 79.63 & 85.19 & 83.33 \\
Electrical Conductivity & 81.95 & 87.42 & 86.92 \\
\hline
\end{tabular}

Table 9. Retention percentage $(\% R)$ of salinity and electrical conductivity at various pressures for Sample 3.

\begin{tabular}{lccc}
\hline Parameter & $\begin{array}{c}\text { Percent retention } \\
\text { at } \mathbf{4} \text { bar }\end{array}$ & $\begin{array}{c}\text { Percent retention } \\
\text { at } \mathbf{6} \text { bar }\end{array}$ & $\begin{array}{c}\text { Percent retention } \\
\text { at } 8 \text { bar }\end{array}$ \\
\hline Salinity & 77.78 & 83.33 & 83.33 \\
Electrical Conductivity & 82.38 & 89.4 & 89.26 \\
\hline
\end{tabular}


Figure 6. Retention of salinity and electrical conductivity vs. pressure for Sample 1.

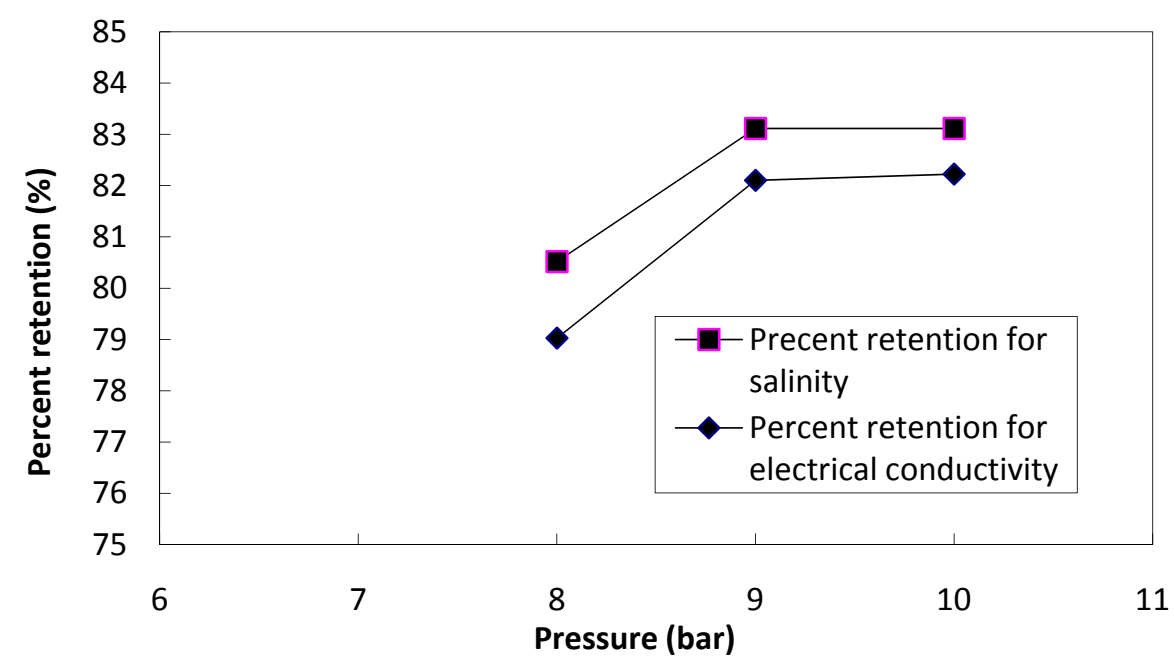

Figure 7. Retention of salinity and electrical conductivity vs. pressure for Sample 2.

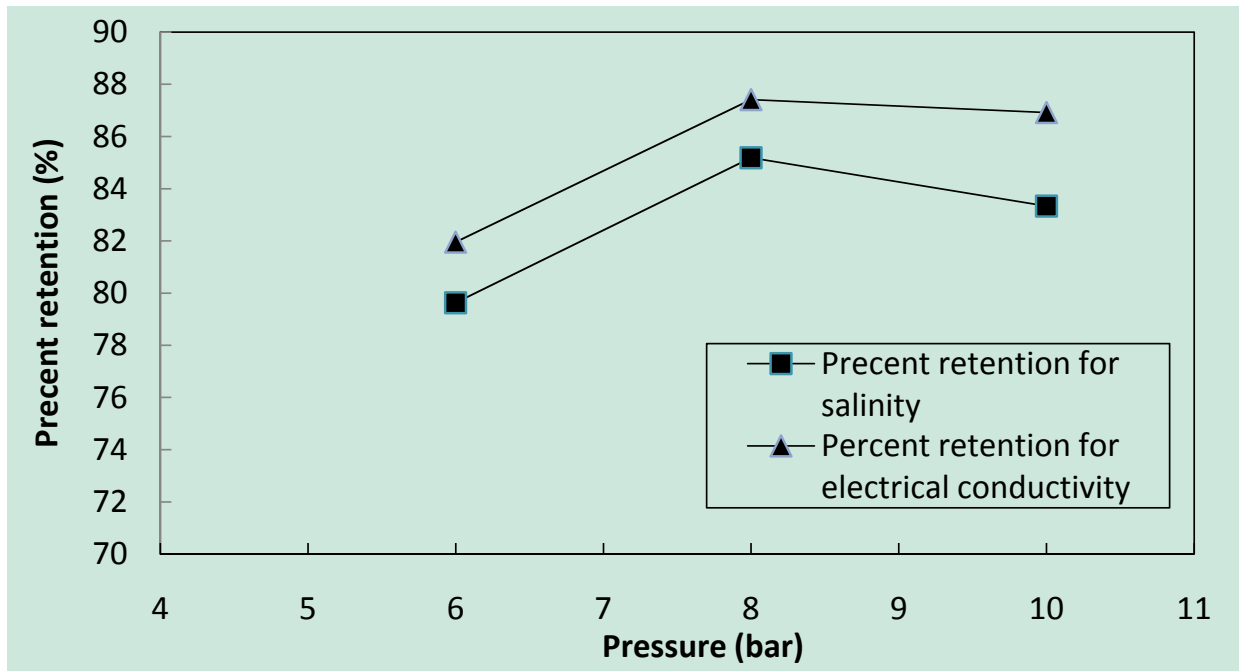

Figure 8. Retention of salinity and electrical conductivity vs. pressure for Sample 3.

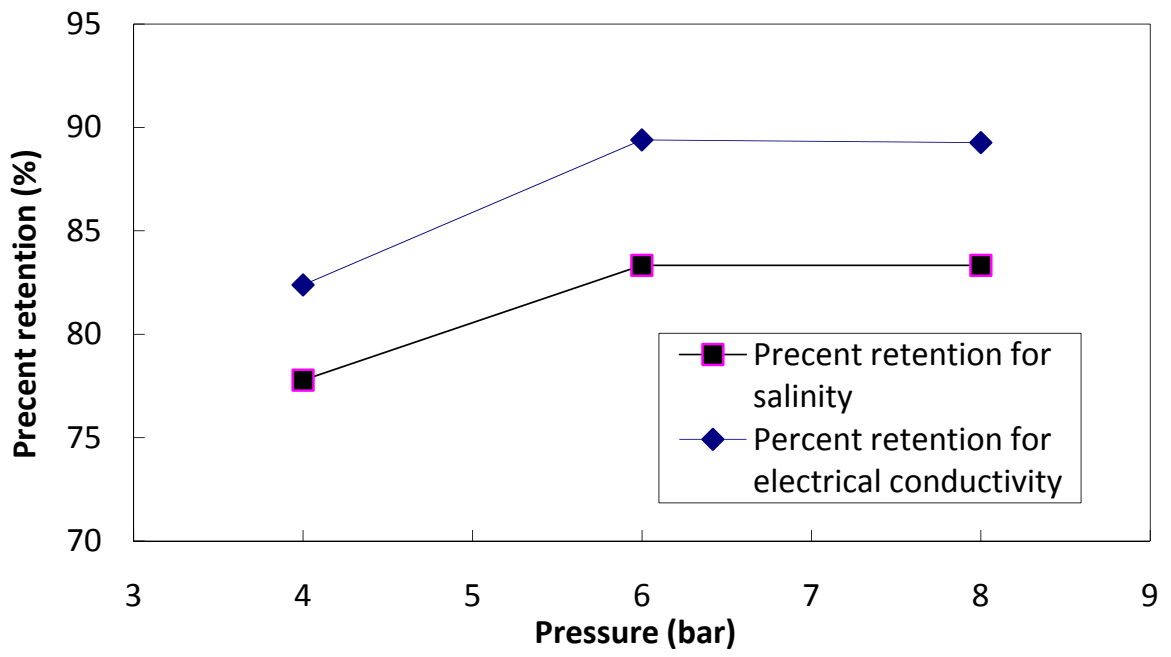




\section{Conclusions}

The nanofiltration study presented herein on diluted seawater samples indicates that the retention percentages of $\mathrm{Ca}^{2+}, \mathrm{Mg}^{2+}$ and total hardness are in the range of 96-98\%, and that the retention of TDS is approximately $79-89 \%$. In addition, the retention percentages of salinity and electrical conductivity are approximately $77-86 \%$ and $79-89 \%$, respectively. Our results are in good agreement with those reported by the manufacturing company. Analysis of Sample 3 shows when sea water is diluted until its EC and TDS are about 8,000 $(\mu \mathrm{S} / \mathrm{cm})$ and 5,000 $(\mathrm{mg} / \mathrm{L})$, nanofiltration of this sample can provide drinking water.

The results show that retention increases with increasing pressure, while at much higher pressures, the retention decreases slightly. This reduction in the retention of salinity and electrical conductivity is more sensitive than the retention of $\mathrm{Ca}^{2+}, \mathrm{Mg}^{2+}$ and TDS. This may be explained by the dominant effect of convection, which causes ions to move through the membrane, compared with diffusion at higher pressures.

\section{Acknowledgments}

The authors gratefully acknowledge the Vice Chancellor of Research and Technology of the Persian Gulf University for financial support. The authors would also like to acknowledge Moosa Panahandeh, head of the Bushehr Department of Water Treatment Works and Laboratory, and Sharareh Ravanshad for their cooperation in sample analysis.

\section{References}

1. Bruggen, B.V.; Vandecasteele, C. Distillation vs. membrane filtration: Overview of process evolutions in seawater desalination. Desalination 2002, 143, 207-218.

2. Raman, L.P.; Cheryan, M.; Rajagopalan, N. Consider nanofiltration for membrane separation. Chem. Eng. Prog.1994, 90, 68-74.

3. Eriksson, P. Nanofiltartion extends the range of membrane filtration. Environ. Prog. 1988, 7, $58-61$.

4. Schaep, J.; van der Bruggen, B.; Uytterhoeven, S.; Croux, R.; Vandecasteele, C.; Wilms, D.; van Houtte, E.; Vanlerberghe, F. Removal of hardness from groundwater by nanofiltration. Desalination 1998, 119, 295-302.

5. Gorenflo, A.; Velazquez-Padron, D.; Frimmel, F.H. Nanofiltration of a German groundwater of high hardness and NOM content: Performance and coast. Desalination 2002, 151, 253-265.

6. Orecki, A.; Tomaszewska, M.; Karakulski, K.; Morawski, A.W. Surface water treatment by nanofiltration method. Desalination 2004, 162, 47-54.

7. Ghizellaoui, S.; Taha, S.; Dorange, G.; Chibani, A.; Gabon, J. Softening of Hamma drinking water by nanofiltration and by lime in the presence of heavy metals. Desalination 2004, 171, 133-138.

8. Ghizellaoui, S.; Chibani, A.; Chizellaoui, S. Use of nonofiltration for partial softening of very hard water. Desalination 2005, 179, 315-322. 
9. Hilal, N.; Al-Zoubi, H.; Mohammad, A.W.; Darwish, N.A. Nonofiltration of highly concentrated salt solutions up to seawater salinity. Desalination 2005, 184, 315-326.

10. Costa, A.R.; de Pinho, M.N. Performance and cost estimation of nanofiltration for surface water treatment in drinking water production. Desalination 2006, 196, 55-65.

11. Galanakis, C.M.; Fountoulis, G.; Gekas, V. Nanofiltration of brackish groundwater by using a polypiperazine membrane. Desalination 2012, 286, 277-284.

12. Rand, M.C.; Greenbeenberg, A.E.; Taras, M.J. Standard Methods for the Examination of Water and Wastewater, 21th ed.; American Public Health Association, American Water Works Association, Water Environment Federation: Washington, DC, USA, 2005.

13. Geraldes, V.; de Pinho, M.N.; Fonseca, C.M.S.; Duarte, E. Spiral-Wound Module Nanofiltration of Surface River Water; E-Water: Hennef, Germany, 2008; pp. 1-13.

(C) 2012 by the authors; licensee MDPI, Basel, Switzerland. This article is an open access article distributed under the terms and conditions of the Creative Commons Attribution license (http://creativecommons.org/Licenses/by/3.0/). 